\title{
PENENTUAN LOKASI SMA NEGERI MENGGUNAKAN DIAGRAM VORONOI BERBOBOT DI KOTA DENPASAR
}

\author{
Melinda Hermanto ${ }^{1}$, TJOKORda BAgUS OKA ${ }^{2}$, \\ I Putu Eka Nila KenCANA ${ }^{3}$ \\ 1,2,3 Jurusan Matematika FMIPA Universitas Udayana, Bukit Jimbaran-Bali \\ e-mail: ${ }^{1}$ melinda_hermanto@yahoo.com , ${ }^{2}$ tjokordabagusoka@gmail.com, \\ 3.putu.enk@gmail.com
}

\begin{abstract}
In school development problem, determining location is one of important things to consider. In this research, the purpose is to determine the location of SMAN 9 Denpasar if it will be built. One of algorithms in computational geometry that can be used to find solution of facility location problem is multiplicatively weighted Voronoi diagram in two dimensions. The result of weighted Voronoi diagram shows the influence of each site to the surrounding area. Then, the location of SMAN 9 Denpasar is obtained by determining the center of the largest empty circle of the weighted Voronoi diagram.
\end{abstract}

Keywords: facility location problem, weighted Voronoi diagram, computational geometry

\section{Pendahuluan}

Pada permasalahan pembangunan sekolah, menentukan lokasi merupakan salah satu hal yang penting untuk dipertimbangkan, sebab apabila suatu sekolah tidak dibangun di lokasi yang tepat maka dapat menimbulkan masalah, salah satunya adalah sekolah tersebut hanya mendapatkan sedikit peserta didik. Permasalahan lokasi suatu fasilitas dikenal dengan istilah facility location problem (FLP). FLP merupakan masalah pencarian lokasi suatu fasilitas yang hendak dibangun, yang diupayakan terletak sejauh mungkin dari lokasi fasilitas sejenis yang sudah ada (Skiena, [5]). Salah satu algoritma dalam geometri komputasi yang dapat digunakan untuk mencari solusi FLP adalah diagram Voronoi.

Diagram Voronoi menunjukkan pembagian suatu wilayah tertentu menjadi beberapa bagian yang disebut cell, di mana masing-masing bagian berisi satu titik lokasi (site). Setiap titik di dalam suatu cell memiliki jarak lebih dekat ke site yang berada di dalam cell tersebut dibandingkan dengan site lainnya pada wilayah tersebut. Dengan demikian, setiap titik pada wilayah tersebut telah dipasangkan dengan site yang terdekat (Berg et al., [2]).

Pada diagram Voronoi biasa, diasumsikan bahwa setiap titik lokasi (site) memiliki bobot yang sama. Dalam beberapa aplikasi praktis, asumsi ini tidak tepat. Diagram Voronoi berbobot merupakan diagram Voronoi rampat yang

\footnotetext{
${ }^{1}$ Mahasiswa Jurusan Matematika FMIPA Universitas Udayana

${ }^{2,3}$ Staf Pengajar Jurusan Matematika FMIPA Universitas Udayana
} 
mengambil bobot yang berbeda ke dalam perhitungan jarak sehingga menjadi jarak berbobot (Okabe et al., [4]). Menurut Aurenhammer and Edelsbrunner [1], diagram Voronoi berbobot dari $S$ (Weighted Voronoi Diagram) adalah pembagian dari suatu bidang sedemikian sehingga setiap titik $p$ di $S$ berhubungan dengan sebuah bagian (region) yang mengandung semua titik $x$ dengan $p$ di $S$ adalah titik terdekat berbobot dari $x$.

Saat ini di Kota Denpasar terdapat delapan buah SMAN. Apabila akan dibangun SMAN yang baru, salah satu faktor yang dapat menjadi pertimbangan adalah banyak lulusan SMPN di sekitar lokasi sehingga agar diperoleh hasil yang mendekati kenyataan, faktor ini dapat menjadi bobot pada setiap titik dalam diagram Voronoi berbobot. Berdasarkan uraian di atas, penulis melakukan penelitian menggunakan diagram Voronoi berbobot untuk mencari solusi masalah penentuan lokasi SMAN yang baru yaitu SMAN 9 Denpasar.

Tujuan penelitian ini adalah untuk menentukan lokasi yang tepat seandainya dibangun SMAN 9 Denpasar dengan mempertimbangkan banyak siswa lulusan SMP Negeri di Denpasar. Pada penelitian ini diasumsikan bahwa faktor yang dipertimbangkan oleh seseorang dalam memilih SMP Negeri atau SMA Negeri hanya faktor jarak, sehingga siswa dari suatu SMP Negeri atau SMA Negeri dapat diasumsikan bertempat tinggal di sekitar lokasi sekolah tersebut. Hasil penelitian ini diharapkan dapat bermanfaat dalam menentukan lokasi pembangunan suatu fasilitas umum dengan faktor pertimbangan (bobot) tertentu.

\section{Metode Penelitian}

Pada penelitian ini digunakan diagram Voronoi berbobot multiplikatif (multiplicatively weighted Voronoi diagram) dan convex hull dalam dua dimensi, dengan koordinat dari SMA Negeri yang telah ada di Kota Denpasar sebagai titik pembangkit. Bobot yang digunakan adalah banyak siswa lulusan SMP Negeri di Denpasar. Algoritma yang digunakan untuk membangun convex hull dalam dua dimensi adalah Algoritma Graham Scan (Johnsonbaugh, [3]).

Adapun data yang digunakan adalah data koordinat SMP Negeri (SMPN) dan SMA Negeri (SMAN) di Denpasar yang diperoleh dari software Google Map serta data banyak kelulusan SMP Negeri di Denpasar pada tahun 2012 yang diperoleh dari Dinas Pendidikan, Pemuda dan Olahraga Kota Denpasar.

Titik-titik koordinat yang telah diperoleh selanjutnya dikonversi ke dalam satuan dekameter (dam). Kemudian titik-titik koordinat tersebut ditranslasikan agar tidak terletak jauh dari titik asal. Bobot masing-masing lokasi SMAN di Denpasar diperoleh berdasarkan jarak Euclid dan jumlah kelulusan SMPN di Denpasar, dengan persamaan berikut:

$$
b_{i}=\sum_{k=1}^{12} \frac{1}{96 \cdot d e_{i k}} \cdot L_{k}
$$


dengan konstanta 96 adalah banyak kombinasi antara delapan SMAN dengan 12 SMPN di Denpasar, $b_{i}$ adalah bobot dari SMAN ke- $i$, $d e_{i k}$ adalah jarak Euclid antara SMAN ke- $i$ dengan SMPN ke- $k$, dan $L_{k}$ adalah banyak siswa lulusan dari SMPN ke- $k$.

\section{Hasil dan Pembahasan}

Diagram Voronoi berbobot dan convex hull dari SMAN yang sudah ada dibangun dengan software Matlab untuk menentukan lokasi SMAN 9 Denpasar.



Gambar 1. Diagram Voronoi Berbobot dan Convex Hull dengan SMANSMAN di Denpasar sebagai Titik Pembangkit

Berdasarkan diagram Voronoi berbobot dan convex hull yang diperoleh, selanjutnya dapat ditentukan lokasi SMA Negeri yang baru. Titik yang menjadi kandidat lokasi adalah titik perpotongan antara convex hull dengan diagram Voronoi berbobot sebanyak 11 titik dan verteks dari diagram Voronoi berbobot yang berada di dalam convex hull yang dibangun sebanyak tiga titik, seperti ditunjukkan pada Gambar 1.

Selanjutnya ditentukan empty circle dari masing-masing titik kandidat tersebut dengan menghitung jarak Euclid antara titik kandidat dengan setiap lokasi SMA Negeri (site). Jarak Euclid minimum di antara titik kandidat dengan setiap lokasi site tersebut merupakan jari-jari dari empty circle. Kemudian empty circle tersebut akan dibandingkan antara yang satu dengan yang lainnya sehingga diperoleh titik koordinat dengan empty circle terbesar. 
Tabel 1. Koordinat dan Jari-Jari Empty Circle dari Titik Kandidat Lokasi

\begin{tabular}{|c|c|c|c|c|}
\hline No & Titik Kandidat & $\boldsymbol{x}(\mathbf{d a m})$ & $\boldsymbol{y}(\mathbf{d a m})$ & Jari-Jari Empty Circle \\
\hline 1 & $\mathrm{~A}$ & 378,396797 & 1098,195215 & 91,835 \\
\hline 2 & $\mathrm{~B}$ & 312,1494372 & 1096,750988 & 92,935 \\
\hline 3 & $\mathrm{C}$ & 597,9494102 & 290,8402639 & 101,350 \\
\hline 4 & $\mathrm{D}$ & 635,6750524 & 440,8397962 & 78,946 \\
\hline 5 & $\mathrm{E}$ & 361,2818049 & 192,4432764 & 116,405 \\
\hline 6 & $\mathrm{~F}$ & 513,3483895 & 193,5363795 & 123,947 \\
\hline 7 & $\mathrm{G}$ & 270,5590192 & 310,9980697 & 90,089 \\
\hline 8 & $\mathrm{H}$ & 248,9148478 & 339,282257 & 78,656 \\
\hline 9 & $\mathrm{I}$ & 535,9905611 & 695,5373428 & 71,000 \\
\hline 10 & $\mathrm{~J}$ & 525,1145598 & 723,3259268 & 69,319 \\
\hline 11 & $\mathrm{~K}$ & 172,2889813 & 725,6766664 & 204,966 \\
\hline 12 & $\mathrm{~L}$ & 380,4369935 & 205,0294898 & 117,014 \\
\hline 13 & $\mathrm{M}$ & 298,735950 & 461,670722 & 67,874 \\
\hline 14 & $\mathrm{~N}$ & 356,464269 & 293,562680 & 80,027 \\
\hline
\end{tabular}

Pada Tabel di atas terlihat bahwa titik $\mathrm{K}$ adalah titik dengan empty circle terbesar dan titik $\mathrm{F}$ adalah titik dengan empty circle terbesar kedua. Seperti ditunjukkan pada Gambar 2, di sekitar lokasi titik K terdapat empat SMP Negeri dan di sekitar SMA Negeri yang terdekat dari titik K telah terdapat SMP Negeri yang lain. Sedangkan pada lokasi titik F, SMP Negeri yang terdekat terletak cukup jauh dari titik F dan telah ada SMA Negeri lain di sekitar SMP Negeri tersebut yaitu SMA Negeri 5 dan SMA Negeri 6. Sehingga dibandingkan titik kandidat lain, titik $\mathrm{K}$ merupakan lokasi yang tepat untuk membangun SMA Negeri yang baru di Kota Denpasar dengan mempertimbangkan jarak berbobot dengan SMA Negeri yang telah ada dan banyak siswa lulusan SMP Negeri di Kota Denpasar. Setelah ditranslasikan dan dikonversi kembali, diperoleh titik K dengan koordinat lintang $-8,646890^{\circ}$ dan bujur $115,205670^{\circ}$ berlokasi di Jalan Wibisana Utara, Kecamatan Denpasar Utara. 




Gambar 2. Lokasi SMA Negeri 9 Denpasar (Warna Hijau)

\section{Kesimpulan}

Berdasarkan hasil penelitian yang telah diperoleh, dapat diambil kesimpulan bahwa dari diagram Voronoi berbobot dan convex hull yang telah dihasilkan, diperoleh lokasi yang tepat untuk membangun SMA Negeri 9 Denpasar memiliki koordinat lintang $-8,646890^{\circ}$ dan bujur $115,205670^{\circ}$. Lokasi tersebut terletak di Jalan Wibisana Utara, Kecamatan Denpasar Utara.

\section{Daftar Pustaka}

[1] Aurenhammer, F. and Edelsbrunner, H., 1984. An Optimal Algorithm for Constructing The Weighted Voronoi Diagram in The Plane. Pattern Recognition, 17(2), pp.251-57.

[2] Berg, M.d., Cheong, O., Kreveld, M.v. and Overmars, M., 2008. Computational Geometry: Algorithms and Applications. 3rd ed. Berlin: Springer.

[3] Johnsonbaugh, R., 2002. Discrete Mathematics Jilid Dua. Penerjemah: Didiek Djunaedi. 4th ed. Jakarta: Prenhallindo

[4] Okabe, A., Boots, B., Sugihara, K. and Chiu, S.N., 2000. Spatial Tessellations: Concepts and Applications of Voronoi Diagrams. 2nd ed. London: John Wiley \& Sons Ltd.

[5] Skiena, S.S., 2008. The Algorithm Design Manual. 2nd ed. London: Springer. 